\title{
INTERNATIONAL DEVELOPMENT COOPERATION OF THE CZECH REPUBLIC IN THE CONTEXT OF EUROPEAN DEVELOPMENT
}

\author{
Ingrid Majerová*
}

\begin{abstract}
:
The paper describes the development cooperation of the Czech Republic within the European Union. It has briefly analyzed the evolution of development cooperation until 2004 when Czech Republic joined the European Union and further the situation from 2004 to present. The paper also evaluated the financial resources for development cooperation, bilateral cooperation and the comparison with other EU Member States, background on the progress of Official Development Assistance in European Union.
\end{abstract}

Keywords: development aid, Official Development Assistance, gross national income, European development policy, bilateral cooperation, multilateral cooperation, priority countries, development projects

JEL Classification: F 35

\section{Introduction}

International development cooperation (IDC) is a concept whose importance is constantly growing in today's increasingly differentiating world. The historical roots of this part of the foreign policy of all developed countries back to the 1940s of the last century are connected not only with the emergence of the United Nations and the liberation movements in colonies but they were also created through the powerpolitical bipolarity, often overshadowed by the economic effects of aid provided.

The aim of development cooperation of any state is to contribute to poverty reduction, economic and industrial development, gradual integration of economies which are supported by the world economy to develop agriculture, development and consolidation of democracy and human rights, establishment of the rule of law and ultimately contribute to sustainable development along with improvement of environment and quality of life of a country.

* Silesian University in Opava, School of Business Administration in Karvina, Univerzitní náměstí 1934/3, CZ - 73340 Karviná (majerova@opf.slu.cz). 
Expert views on what all can be included in the international development cooperation vary. Taking into account all the expenses, which could fulfill the above conditions, we could include in this kind of cooperation spending on international development aid, humanitarian assistance but also military aid. Looking closely on the structure of IDC, this cooperation can be further divided by purpose. In addition to military aid we can find the aforementioned humanitarian assistance and development assistance. We can further split according to the international development cooperation provider to government, non-governmental organizations (NGOs) or combined. According to the method the financial assistance covers the dividing of grants and loans or capital flows and public finances, which must meet the non-commercial criterion, in the case of loans to be provided on concessional terms (lower interest rates and longer maturity). According to the number of involved parties, the foreign share of bilateral cooperation, which is based on the principle of "donor countries - the recipient countries" and the multilateral based on the principle of "donor international organizations - recipient countries".

In connection to the provision of international development aid it can be primarily defined on the basis of its functioning, the most widely used and most sophisticated definition of Development Assistance Committee (DAC), the Organization for Economic Cooperation and Development (OECD). DAC defines the term of international development aid through the Official Development Assistance, intended to developing countries by GNI level: since 1969 to 1992 they were divided into four income-based groupings: Least Developed Countries, Other Low Income Countries, Lower Middle Income Countries and Territories and Upper Middle Income Countries and Territories. In 1993-2004, international aid was divided into two groups: Part I (Official Development Assistance - ODA) for "traditional" developing countries and Part II (Official Assistance - OA) for countries in transition and "more advanced" developing countries. In 2005, the DAC therefore reverted to a single List of ODA Recipients, abolishing Part II.

The Committee refers to all development aid flows to countries and territories on the list of ODA recipients at the multilateral development institutions, which are provided by public authorities, including state and local governments or their executive bodies. Each transaction is given to promote economic development and welfare in developing countries, is concessional (less than the market rate) and under favourable conditions (a subsidy of at least $25 \%$ ). (OECD, 2008) Provided Official Development Assistance is further divided into food aid, capital flows and technical assistance and cooperation.

In further interpretation there will be analyzed (due to the range of issues) the development of EU/ODA with particular emphasis on its providing to ACP countries (79 African, Caribbean and Pacific economies from total of 152 recipients of ODA, receiving about $67 \%$ of total ODA amount). The international development assistance is focused provided by the Czech Republic in the context of its development in the EU as well. 
In the article there was used one of three methods of development assistance measurement - its share of ODA to GNI (in \%) - as the most objective countries involvement in development assistance. Other methods are total ODA and ODA per capita (see Figure 1).

\section{Progress of European Development Policy}

The concern of the European Union is to prevent poverty, instability and conflict in the world. Therefore ODA is an important policy of the European Union to the third countries. This policy is realized through a variety of support programs financed by the EU budget, the European Investment Bank or the European Development Fund (EDF) either by an association of developing countries to the EU, and developing specific programs. Participation of member countries in the EDF is not only an unwritten obligation but also a political commitment of EU member states. On the implementation of development projects and other contracts financed from the EDF may participate in only the bodies of the countries contributing to this fund.

Programs and projects controlled by the European Community, called community support, account for approximately one fifth of the expenditure, while the majority of assistance is provided directly by the member countries of the Union. It therefore follows that proper use of terminology - while the EC development cooperation relates only to the common activities of the EU, the European Union cooperation covers cooperation in the development of the Community as a whole as well as development cooperation among the Member States. The following lines will be analyzed in the field of IDC of the EU.

\subsection{History of EU Development Policy until 2000}

The European Union (formerly European Community - EC) in the process of deepening integration has also gradually formed and changed relations with the countries which we call developing today. Member States of the former EC were based on the needs to maintain economic and political ties with countries that for centuries dominated.

The term was firstly used in association with the Treaty of Rome establishing the EC, which came into force on 1 January 1958. It was the creation of a "special relationship" in particular with France, Italy, Belgium and the Netherlands overseas regions that previously were part of their colonial empire. In 1963, the first phase was implemented by the association, in the so-called agreement Yaounde I. In 1968, Arusha I agreement should have been closed to extend the association of the three East African Anglophone countries (Kenya, Uganda and Tanzania). However, the agreement did not enter into force because it was not ratified. After the expiry of Yaounde I in 1969, the agreements Yaounde II and Arusha II were signed both with five-year validity. The essence of both contracts was the liberalization of the movement of goods, persons and capital (creation of free trade zone) and financial and technical cooperation. Regime should 
be restored according to reciprocal preferences complemented by the creation of the European Development Fund, which was used to fund selected projects in the accession countries. Although there was a reduction of protectionist measures, bilateral trade rose only slightly, the problem was especially trade in agricultural commodities, migration of capital and labour were talking about political instability in the developing region. Improvements came up with the next phase.

In 1975, two previous agreements were terminated and these have been replaced by the so-called Lomé I agreement which is considered as a new, second phase of the association. Its signatories were 9 EC Member States and 46, then 58, the developing countries in Africa, Caribbean and Pacific (ACP), a former British, Belgian, Dutch and French colonies. ${ }^{1}$ It was the duty-free opening of the EC market for agricultural and raw material exports from ACP (excluding bananas, sugar and rum). To eliminate fluctuations in the prices of these commodities on world markets STABEX system was introduced, which in the event of a decrease of $7.5 \%$ compared with the previous year to provide financial compensation for the affected economies (this system is due to the factor of delay and red tape, proved not being very effective). In this Agreement the main emphasis has been placed on industrial development, which can be regarded as the beginning of the sectoral approach to development assistance.

In 1979, an agreement Lomé II was signed for 12 EC states and the existing 58 developing countries and the mechanism of association of the system SYSMIN was expanded. It was again a stabilizing mechanism, this time for the market with mineral resources (bauxite, copper, tin, etc.). The aim was once again to help those developing countries whose primary export item was mentioned material. The intervention occurred when the drop in exports of one commodity was $10 \%$ and this commodity had to be at least $15 \%$ of the country's export structure. The problems with the implementation of trade on the basis of this system were similar to this STABEX system.

Lomé III agreement was signed in 1984 among 12 EC states and 66 ACP countries with five-year validity. The main objective of the agreement was described in supporting the economic, cultural and social development of ACP countries and strengthening their relations with the EC. The substantive areas of cooperation agreements with content Lomé I to Lomé III were fundamentally indistinguishable. Lomé III implementation despite some positive elements was not evaluated as successful. The economic situation in most ACP countries toward the end of 80 years proved to be better than before the agreement was concluded.

The most comprehensive and most sophisticated Lomé IV agreement was signed among the 12 EC Member States and 66 ACP countries in 1989. Emphasis was placed on it in the balance between economic objectives maintaining the environment and enhancement of natural and human resources, including human rights (which

1 ACP Group was formally founded in 1975 by the Georgetown Agreement and currently includes 79 countries. The group has its own institutions and decision-making and in conjunction with the EU through common institutions. 
foreshadowed the political dimension of the other agreements). These objectives and principles have been established with regard to the diverse conditions in individual countries and the cooperation has focused on the development of individual countries, (sub) regional integration and clusters. Lomé IV was compared with the previous agreements, fixed at 10 years and the bulk of funding was devoted to structural changes in developing countries. This agreement was given a special part of the provisions relating to least developed, landlocked and island ACP countries, which represent over $60 \%$ of the signatory developing countries (44 from 69 , respectively 71 countries). Although satisfactory results were not achieved - economic situation of associated countries was not better, their financial situation worsening as a result of developments in agricultural commodity prices on world markets and STABEX was not enough to compensate for these developments.

Neither the development of trade between the EC and the ACP countries had an increasing trend in that period, as shown in Table 1. One of the causes can be seen in the system of high agricultural subsidies in the EU resulting in lack of price competitiveness of imports from developing economies.

Table 1

Development of Trade among the EC and the ACP in 1980 and 1990

\begin{tabular}{|l|l|l|l|c|}
\hline \multirow{2}{*}{} & \multicolumn{2}{|c|}{1980} & \multicolumn{2}{c|}{1990} \\
\cline { 2 - 5 } & mil. ECU & $\%$ & mil. ECU & $\%$ \\
\hline Export to EC & 17,216 & 10.4 & 16,649 & 6.4 \\
\hline Import from EC & 20,889 & 11.5 & 20,195 & 5.8 \\
\hline
\end{tabular}

Source: Němečková et. al. (2006, p. 15), own calculation

Therefore the revised Lomé IV agreement was signed in Mauritius in 1995, which established the relationship between the EU and ACP political dialogue including its extension on issues of foreign policy and security. But even the revision did not improve the situation of developing countries, which should change the Cotonou Agreement (more in Chapter 2.2).

Since 1990 development cooperation - in connection with the political changes in the global economy - I have already mentioned one change: a part of the assistance previously intended for the poorest countries has been transferred to assist countries of Central and Eastern Europe and former Soviet Union countries (grouped in the Union of Independent States) to support their transformation and also to developing countries with high GNI (OA - Official Assistance). An increase from USD 0.36 billion in 1989 to 6.57 in 1991 to USD 8.42 billion in 1995 corresponded to about $15 \%$ of current total assistance to developing countries. The cause of this movement were both security interests (stability for Russia and the connection to NATO countries in Central and Eastern Europe) both the interests of business, which was placed before the destabilizing threat in developing countries. 
Looking at which countries and how much (including percentage terms) went OA in the years 1991-2000, can be traced back two main groups (see Table 2) - prevailing in the countries of the former socialist bloc, which is - up to with one exception - twelve largest recipients with a share of total aid (in 2000) just under 20\%. The second group consists of "high income" countries, which began later draw Official Assistance - 10\% share with Israel but also the Bahamas, Singapore and Brunei.

After the EU enlargement in 2004 (and the removal of the former transition economies from the list of the recipients OA), the two parts went together and the former development aid for them was transformed into the standard instruments of EU structural policy.

Table 2

The Main Recipients of OA in the Years 1991-2000 (in billion USD and \%)

\begin{tabular}{|l|r|r|r|r|}
\hline & \multicolumn{1}{|c|}{$\mathbf{1 9 9 1}$} & \multicolumn{1}{c|}{$\mathbf{1 9 9 5}$} & \multicolumn{1}{c|}{$\mathbf{2 0 0 0}$} & Share in 2000 \\
\hline Russia & \multicolumn{1}{|c|}{563.5} & $1,610.1$ & $1,564.6$ & 19.5 \\
\hline Poland & $2,508.3$ & $3,790.4$ & $1,396.2$ & 17.4 \\
\hline Israel & --- & --- & 800.0 & 10.0 \\
\hline Ukraine & 368.3 & 319.1 & 541.0 & 6.7 \\
\hline Czech Republic & 230.6 & 147.9 & 438.2 & 5.5 \\
\hline Romania & 321.1 & 275.6 & 432.1 & 5.4 \\
\hline Bulgaria & 316.1 & 113.7 & 311.1 & 3.9 \\
\hline Hungary & 626.0 & 244.0 & 252.2 & 3.1 \\
\hline Slovak Republic & 114.5 & 98.2 & 113.1 & 1.4 \\
\hline Lithuania & 4.0 & 179.6 & 99.0 & 1.2 \\
\hline Latvia & 3.4 & 63.6 & 91.1 & 1.1 \\
\hline Estonia & 15.4 & 58.2 & 63.8 & 0.8 \\
\hline Cyprus & --- & --- & 54.5 & 0.7 \\
\hline Belarus & 187.0 & 222.9 & 39.6 & 0.5 \\
\hline Bahamas & --- & --- & 5.5 & 0.1 \\
\hline Singapore & --- & --- & 1.1 & 0.0 \\
\hline Brunei & --- & --- & 0.6 & 0.0 \\
\hline Catarrh & --- & --- & 0.5 & 0.0 \\
\hline Other & $6,547.2$ & $8,417.3$ & $8,020.2$ & 100 \\
\hline Total & & & & 22.6 \\
\hline
\end{tabular}

Source: White (2002, p. 19)

The above changes are also related to another trend, which is an increase in the share of humanitarian assistance in certain areas. Earlier conflicts based on ideological basis began to grow in many countries by armed conflicts which always bring the need of humanitarian assistance. Thus there was a transfer of funds from long-term 
development projects and programs to help those affected by the conflict regions. In the period 1990-2000, the official humanitarian assistance (with the highest proportion of food aid) has doubled from USD 2,100 million to 5,900 million and the share of total ODA increased from 5.83\% to $10.5 \%$ (Macrae, Harmer, 2004, p. 3). These figures may be misleading, however, because many donors have in spending on humanitarian assistance to count the expenditure on refugees coming from developing countries.

An increasing trend is the so-called debt relief, or development assistance in the form of debt write-off as a legitimate form of development assistance. While in the years 1979-1988 the debt relief for the type of assistance was to the eighth spot, in the years 1989-1998 the debt write-off has already enjoyed the fifth place, in the years 1999-2008 even the second (for social infrastructure and services). On the other hand, there are also EU Member States - Belgium, Denmark, the Netherlands, which in the past twenty years significantly reduced the loan, or even completely stopped lending the most indebted economies.

During this period making decline in the share of multilateral aid in total ODA has started - while in the 1980s of the last century the type of assistance was 35\% ODA/ DAC, in 1990s years later only 30\%. Developed economies were expressing "their reservations about the effectiveness and accountability of some institutions. This decline would have been even more dramatic had it not been substantial growth in support of organizations such as UNHCR, UNICEF and WFP, which focus on humanitarian assistance." (Halaxa, p. 12) Initially the trend followed by the EC Member States/ DAC but since the mid-nineties multilateral support has an upward trend (in 1995 it was $35 \%$, in 2000 already $39 \%$ ).

\subsection{Progress of EU Development Policy since 2000}

"Structural problems of their own economies of the ACP, which limit their competitiveness, lack of investment and lack of industrialization, combined with the economic problems arising from the international environment and the existence of sophisticated mechanisms disguised protectionism of the European market, are all factors that led to the failure of the old system. " (Kenneth, 2002, p. 21) The EU's relations with developing countries did not therefore develop under the assumptions of the development cooperation agreements signatories, which over the years recorded more or less successful change of orientation to the wider economic form - not only economic but also social and cultural.

The basis of this broad approach to development cooperation has become the Cotonou Agreement, signed in 2000 with a term of twenty years and the ACP group of 78 countries has on its basis right to development aid from the European Union provided opening their markets to the Union's products. This agreement has brought not only the extension of the signatory countries of the ACP group but particularly the involvement of the whole society, ie. NGOs, public and private enterprises in developing policies, termination of inefficient systems STABEX and SYSMIN and accession to the 
reciprocal trade relations through agreements on economic cooperation EPA(Economic Partnership Agreement).

While the introduction of the first two points did not have any side issues, otherwise it was at the point of the third. One of the problems that occurred during the negotiation of the EPA in the years 2002-2009 (the final agreements were signed with nearly two-year delay of the originally planned end of 2007), the growing diversity of the groups was in terms of the trade regime and economic interests against the EU. Least developed countries (LDCs) trade with the EU since 2001 in the beneficiary regime the EBA (Everything but Arms), while some countries outside the LDCs have signed interim EPAs, in order to avoid crossing the GSP (Generalized System of Preferences). Some ACP countries are major exporters and have great interest in entering the EU market, another difficult situation of dumped exports from the EU, or fail to exploit market access due to technical constraints. The extent and depth of regional integration is also very different from the sub-region and even within a particular sub-region's economic situation and the commercial strength of a very diverse country.

Between 2000 and 200713.5 billion euro were allocated to development aid from the EU budget, compared with 9.9 billion euro in the previous EDF period of Lomé IV, which corresponded to 13.132 billion ECU - ACP countries received 12.967 billion and OCT countries (Overseas Countries and Territories) 0.165 billion ECU. In the period 2008-2013, falling to 10 European Development Fund to these countries to draw around three billion euro per year, the total amount should be 22.682 billion of which the ACP countries receive 21.966 billion, the countries OCT 0.286 billion euro and the rest will cover the issues the European Commission (EU, 2007). The innovation in the 10th EDF is the creation of "incentive amounts" for each country. During this period, the EU allocated 255 million euros to "States of one commodity" - there are the countries in which a drop of more than twenty percent of the economy and fluctuations in its prices on the world market, cause economic problems.

Looking at the official development assistance of EU in the new millennium we can divide donor states into three groups: both in terms of total expenditure and in terms of their share of contributions to ODA to gross national income and in terms of spending on ODA/capita (in euro prices in 2007). Due to the different sizes of member economies, it is clear that the representation of various groups is different (see Figure 1). Highest explanatory power of the country's involvement in development assistance has, in addition to the share of ODA/GNI, especially the last indicator, and the ODA/ capita. 
Figure 1

The Share of EU Member States on Various Aspects of ODA
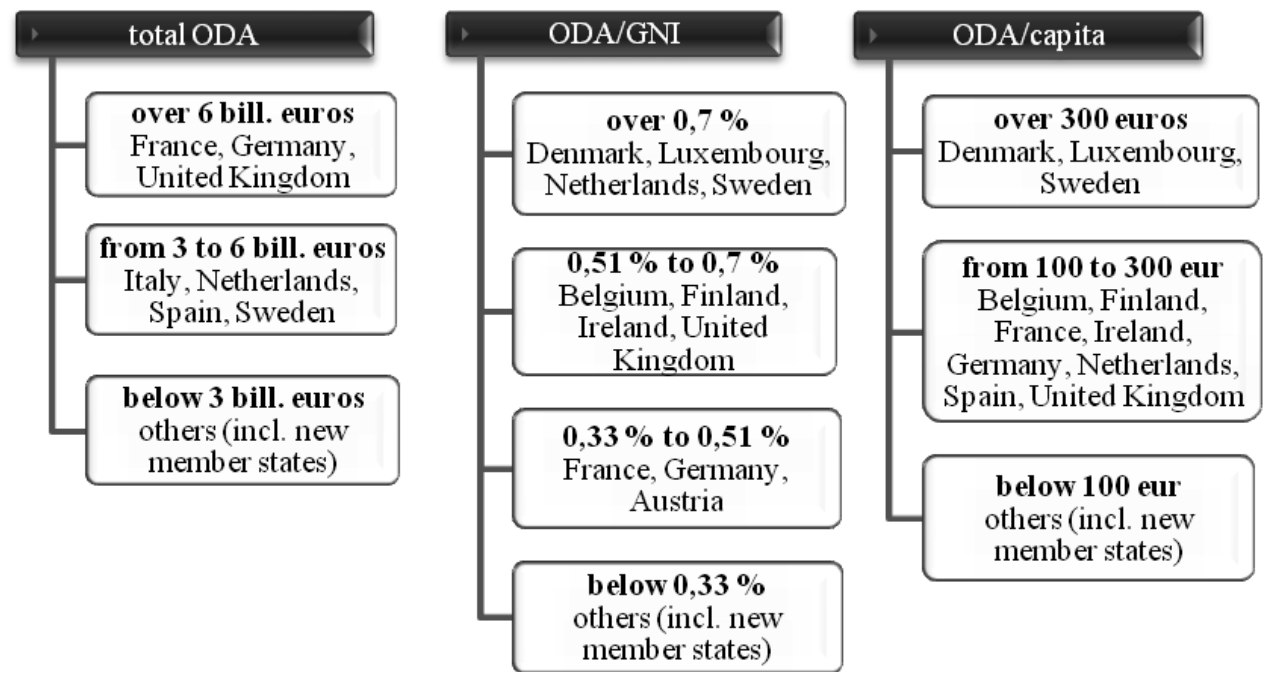

Source: EU (2010 b)

It is clear from the above figure that most donors need not be at the same time donors with the highest proportion of development assistance per capita and the creation of national income, as also illustrated in Table 3. This report also clearly shows that States meet the criterion of commitment of the EU summit in Barcelona in 2002, and the achievement of at least $0.33 \%$ ODA/GNI for each Member State by $2006,0.51 \%$ for 2010 and $0.7 \%$ ODA/GNI by 2015 .

The commitment to meet the majority of Member State (except Italy, Portugal, Greece and Spain with a slight difference), while the second - the gray box - only eight out of fifteen countries (Belgium, Finland and the Great Britain last year) and long-term commitment to achieve $0.7 \%$ of GNI of only four States (marked in bold), which does not sound in favour of EU development policy. Table does not include the new EU 12 countries for which the criterion to achieve the share of ODA/GNI is lower: $0.17 \%$ for 2010 and $0.33 \%$ in 2015 . 
Table 3

Development of ODA/DAC in the Years 2000-2009 (\% of GNI)

\begin{tabular}{|l|c|c|c|c|c|c|c|c|c|}
\hline & $\mathbf{2 0 0 1}$ & $\mathbf{2 0 0 2}$ & $\mathbf{2 0 0 3}$ & $\mathbf{2 0 0 4}$ & $\mathbf{2 0 0 5}$ & $\mathbf{2 0 0 6}$ & $\mathbf{2 0 0 7}$ & $\mathbf{2 0 0 8}$ & $\mathbf{2 0 0 9}$ \\
\hline Belgium & 0.37 & 0.43 & 0.60 & 0.41 & 0.53 & 0.50 & 0.43 & 0.48 & 0.55 \\
\hline Denmark & 1.03 & 0.96 & 0.84 & 0.85 & 0.81 & $\mathbf{0 . 8 0}$ & $\mathbf{0 . 8 1}$ & $\mathbf{0 . 8 2}$ & $\mathbf{0 . 8 8}$ \\
\hline Finland & 0.32 & 0.35 & 0.35 & 0.37 & 0.46 & 0.40 & 0.39 & 0.44 & 0.54 \\
\hline France & 0.31 & 0.37 & 0.40 & 0.41 & 0.47 & 0.47 & 0.38 & 0.39 & 0.46 \\
\hline Ireland & 0.33 & 0.40 & 0.39 & 0.39 & 0.42 & 0.54 & 0.55 & 0.59 & 0.54 \\
\hline Italy & 0.15 & 0.20 & 0.17 & 0.15 & 0.29 & 0.20 & 0.19 & 0.22 & 0.16 \\
\hline Luxembourg & 0.77 & 0.78 & 0.86 & 0.79 & 0.79 & $\mathbf{0 . 8 9}$ & $\mathbf{0 . 9 2}$ & $\mathbf{0 . 9 7}$ & $\mathbf{1 . 0 1}$ \\
\hline Germany & 0.27 & 0.27 & 0.28 & 0.28 & 0.36 & 0.36 & 0.37 & 0.38 & 0.35 \\
\hline Netherlands & 0.82 & 0.81 & 0.80 & 0.73 & 0.82 & $\mathbf{0 . 8 1}$ & $\mathbf{0 . 8 1}$ & $\mathbf{0 . 8 0}$ & $\mathbf{0 . 8 2}$ \\
\hline Portugal & 0.25 & 0.27 & 0.22 & 0.63 & 0.21 & 0.21 & 0.22 & 0.27 & 0.23 \\
\hline Austria & 0.34 & 0.26 & 0.20 & 0.23 & 0.52 & 0.47 & 0.50 & 0.43 & 0.30 \\
\hline Greece & 0.17 & 0.21 & 0.21 & 0.16 & 0.17 & 0.17 & 0.16 & 0.21 & 0.19 \\
\hline Spain & 0.30 & 0.26 & 0.23 & 0.24 & 0.27 & 0.32 & 0.37 & 0.45 & 0.46 \\
\hline Sweden & 0.77 & 0.84 & 0.79 & 0.78 & 0.94 & $\mathbf{1 . 0 2}$ & $\mathbf{0 . 9 3}$ & $\mathbf{0 . 9 8}$ & $\mathbf{1 . 1 2}$ \\
\hline United Kingdom & 0.32 & 0.31 & 0.34 & 0.36 & 0.47 & 0.51 & 0.36 & 0.43 & 0.52 \\
\hline
\end{tabular}

Source: UN Statistic (2010), own calculation

\section{Progress of International Development Cooperation of the Czech Republic to 2004}

Czech or Czechoslovakian ODA history goes back to the beginnings of decolonization after World War II when the nature of this assistance has been influenced by more power-political interests than the pursuit of economic support for the host economy. The turning point came after 1989 when development assistance through its politicization has been in decline and its rebirth in the form, in which it is known today, starts in 1995 when the Czech Republic joined the OECD and then develops after it joined the EU in 2004. This chapter analyzes how the situation before the "Velvet Revolution" was, thus converting the system during the transformation and evolution of this measure until 2004.

\subsection{Development Cooperation in Czechoslovakia before 1989}

After the World War II Czech development cooperation was based on political direction. The former Czechoslovakia was heavily involved in development assistance even though these cooperation showed unstable development - while in the 1950s of the last century it has risen sharply, in the 1960s (due to the reform efforts) has been in decline, in the late 1970s it was upswing again, which was the most intense in the 1980s. 
It is more than clear that the period of centrally planned economy and fighting of the two politically and economically different (groups of) states of the power preponderance, was the development cooperation policy of the subordinate position in the global economy. Soviet Bloc countries directed their assistance solely to the states, which political orientation had tremendous interest.

During this period we could view the current development policy of Czechoslovakia characterized as inefficient. We have to realize that it was all ideology and therefore this assistance was directed to developing countries, which were identified as non-European socialist countries (Cuba, Mongolia, North Korea, Vietnam, Laos and Cambodia), countries of priority interest (Ghana, Guinea, Mali, Afghanistan, Angola, Ethiopia, South Yemen, Mozambique and Nicaragua), the countries of Czechoslovak interests in terms of developing long-term political and economic interests (Algeria, Benin, Guinea-Bissau, India, Iraq, Iran, Congo, Libya, Mexico, Nigeria, Syria and Venezuela). Other developing countries, whose economic and political system did not satisfy, were labelled as "country in the thrall of imperialism" (Zahraniční rozvojová spolupráce, 2008), did not receive development assistance and Czechoslovakia almost maintained with them no economic relations.

Development aid has been divided to material assistance, technical assistance in the form of scholarship assistance, increases in the prices of imported raw materials and also in long-term government loans for the procurement of Czechoslovak goods and services, including investment units. Financial budget for development assistance in the 1980s ranged from about 900 million per year, which - with volume then measured national income of 500 billion - accounted for $0.18 \%$.

\subsection{Czech Development Cooperation in the years 1990-2004}

The year 1989 marked not only for the former Czechoslovakia for a change of political system and emerging economic transformation but in connection with those events as well as a shift in international development cooperation. The immediate years after the collapse of the socialist system meant a huge drop in the volume of ODA, it was because of two reasons - first the economy was focused on the transformation to a market economy, and it needed the support and second because it showed highly significant and negative attitude of distrust of the public and politicians for the continuation of ODA policy basis (Kocourek, 2006). Cooperation with developing countries was therefore not on the basis of development, but economic cooperation.

The situation changed in 1995 with joining the OECD and as one of the obligations of Member States there is also helping developing economies, the Czech Republic renewed this form of cooperation even as first of all the transition countries (in 1996) and ranked as a group of the so-called emerging donors (Kaplan, 2005). An important document for the provision of ODA has become Principles for the Provision of International Development assistance in 1995, which provides inter alia for the basic condition for providing foreign aid, which was "the recipient country efforts to resolve 
their situation and provide assistance to effectively use" (Vláda ČR, 2009) and the criteria for the prioritization of foreign aid: "urgency (social and economic level of the receiving country), relationship of the recipient country to the Czech Republic (the possibility of consolidating existing or create new desired political and economic ties), level of democracy and human rights in the recipient country and degree of necessity (effective cooperation of the recipient country, the reliability of distribution of relief), including the ability to control use." (ibid)

When deciding about assistance to a particular country all the above criteria was considered and it was also stated that "with regard to current priorities and national interests, the government may privilege one criterion over the other," (ibid) which is also due to China as one of major recipients of bilateral aid and the minimum number of beneficiary countries to LDCs (13\%), very often practiced.

The original intention of this approach was a gradual increase in the volume of funding for foreign aid to the 1.6 billion CZK in 2000, which, by reason of the influence of various factors like the economic problems, reduce budgetary expenditure, the costs associated with removing the effects of flooding, failure to ensure that - in 1997 it was projected to reduce by half the amount, in 1998 even by $60 \%$, the amount allocated in 1999 was at level of 1996.

IDC of this period was subsequently criticized by the government and NGOs for its non-conception (many isolated projects) over territorial and sector widespread. ${ }^{2}$ This fragmentation, combined with low levels of assistance meant that the most of the money flowed to relatively small projects, thereby reducing the contribution of money management and complicated the whole system.

Based on the above criticisms the Czech government adopted in December 2001 Concept of Foreign Development Assistance of the Czech Republic for the period 2002-2007 (MFČR, 2001), which had the shortcomings. This section of the paper will focus on its performance in the first two years, IDC has undergone to other treatments since Czech EU entry. The legal document did not just organizational changes but also more integrated foreign aid to foreign policy in particular the territorial specification, which brought a narrowing of assistance to twenty of the fifty states (Yugoslavia and Kosovo, Bosnia and Herzegovina, Macedonia, Uzbekistan, Ukraine and Kazakhstan, Lebanon, Palestine and Yemen, Vietnam, Mongolia and Afghanistan, Namibia, Angola, Mali, Burkina Faso and Ethiopia, Nicaragua, El Salvador and Bolivia).

In terms of prospects for the Czech Republic to the European Union, there was in period a very important commitment of EU Member States declared at the Barcelona Summit in March 2002, i.e. to pursue at least $0.33 \%$ ODA/GNI for each Member State, and $0.39 \% \mathrm{ODA} / \mathrm{GNI}$ as the average for the whole EU in 2006 and $0.51 \%$ in 2010 (long-term goal is to achieve the UN $0.7 \%$ ODA/GNI by 2015).

2 In the period 1996-2000, the major projects of the Czech foreign development aid made at the forty countries, in 2001 even at fifty states. 
Taking into account the amount of funds spent on development cooperation, this period can be considered as being successful. The total volume of the Czech ODA in 2003 reached CZK 2.556 billion in comparison with almost half the figure reported in 2002. Part of the increase must be attributed to featuring more of the CZK against the USD (koruna strengthened against dollar yearly by $16 \%$ ), in which official statistics indicate but even so real growth in ODA between 2002 and 2003 amounts to $69 \%$. This is the highest annual growth in the history of Czech ODA and Czech Republic had higher growth than any of the existing members of the OECD/DAC (the Belgium reported the increase of $43 \%$ ).

\section{Development of International Development Policy of the Czech Republic after 2004}

The year 2004 was significant for the Czech Republic not only in terms of acceptance into the European Union but also from the perspective of development cooperation, it ceased to be the recipient of this type of assistance (in OA) and became its sole donor. Already at the time of Czech international development cooperation (IDC) conception for the years 2002-2007 has been designed in two phases: before (first phase) and after entry into the European Union (second phase). Even before its official entry into the government in March 2004 it accepted principles of international development cooperation after joining the EU, which meant a further shift in policy of foreign aid. First, international cooperation was built on a comprehensive medium-term strategy, which should enable all parties the efficient planning of activities and second both have been set (due to the constant criticism of fragmentation ODA) to further reduce the priority recipient economies. In 2007, another resolution was adopted by the government to transform the system of the Czech Republic IDC which prepared the conditions for adoption of new principles of ODA for the period 2010-2015 and it should be (after completion by the end of 2010) the input of the Czech Republic to the OECD Committee DAC.

Main part of IDC was established with the cooperation of ten countries - eight priorities (Angola, Bosnia and Herzegovina, Yemen, Moldova, Mongolia, Serbia and Montenegro - since 2006 only Serbia - Vietnam and Zambia) and two medium priority countries (Afghanistan and Iraq). Selection of the recipient economies was based on territorial priorities and sector priorities were defined - immigration, industry promotion, education, health, agriculture, environment and sustainable development.

With the reduction in the priority recipients of twelve economies, especially the African and Latin American countries, only four belong to the group of LDCs. Another four Burkina Faso, Ethiopia, Mali and Namibia - have been scrapped and the share of LDC economies on the overall bilateral assistance fell in 2004-2006 to an average of $11.9 \%$ (Němečková et al., 2006).

In addition to the priority countries for bilateral cooperation in the field of development cooperation, there is also another group of priority countries in the so-called 
transformational program of cooperation where the beneficiaries do not meet the condition criteria of democracy and it helps them to achieve. Among recipients include Burma (Myanmar), Belarus, Bosnia and Herzegovina, Georgia, Iraq, Moldova, Cuba and Ukraine (MZV ČR, 2009). Since 2009 it has started IDC collaboration with the so called non-programming countries, $i e$. countries that are not priority, but they are initiated new projects (MZV ČR, 2010). These countries are Ethiopia, Georgia, Cambodia, Kosovo and the Palestinian autonomous territories. Other developing countries which are being finalized started projects are among the non-priority countries.

Territorial structure of bilateral foreign aid and its evolution from 2004 to 2008 is shown in the Figure 2. For comparison the year 2003 is also shown, when the reduction was not yet implemented in the recipient economies. From these data it is evident that the orientation of foreign aid to the Middle East and North Africa moved into South and Central Asia.

Figure 2

The development of the Territorial Determination of Czech bilateral foreign Aid in the Period 2003-2008 (in \%)

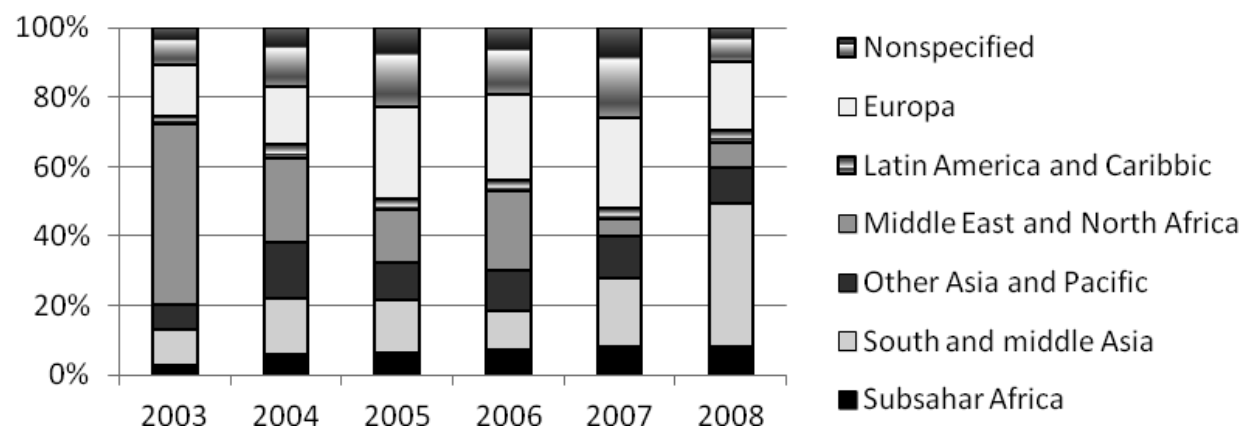

Source: Adamcová (2006, p. 76), Macrae, Harmer (2004), own calculation

"The Czech Republic as a Member of the European Union and the international community of democratic and economically developed countries recognizes the principle of solidarity among people and among states and accepts its responsibility for resolving global problems. One expression of this attitude is the Official Development Assistance, which is an integral part of Czech foreign policy. CR in accordance with $E U$ principles and the protection of its interests conducts and provides its own IDC and both bilateral and multilateral basis." (Preambule Usnesení vlády č. 302, 2004)

\section{Comparison of the Development Cooperation with other EU Member States}

Since its entry into the European Union the Czech Republic is compared with eleven other New Member States, the taxpayers an above-average foreign aid, which puts it in fourth place behind Cyprus, Malta and Slovenia as shown in Figure 3. 
From this figure it is clear that the economic development of these countries most affected the amount of ODA - the most progressive development of Latvia has experienced, while records fell in ODA of Malta. Least stable in the field of international development cooperation are Hungary and Poland, while stable development of the Czech Republic was recorded along with Slovenia and Lithuania. It is also obvious that the only state that currently meets the criteria of holding $0.17 \%$ of GNI is Cyprus and it seems that remain economies are problematic in approaching to this criteria.

Figure 3

Comparison of ODA Development of New EU Member States in the Years 2004-2008 (\% of GNI)

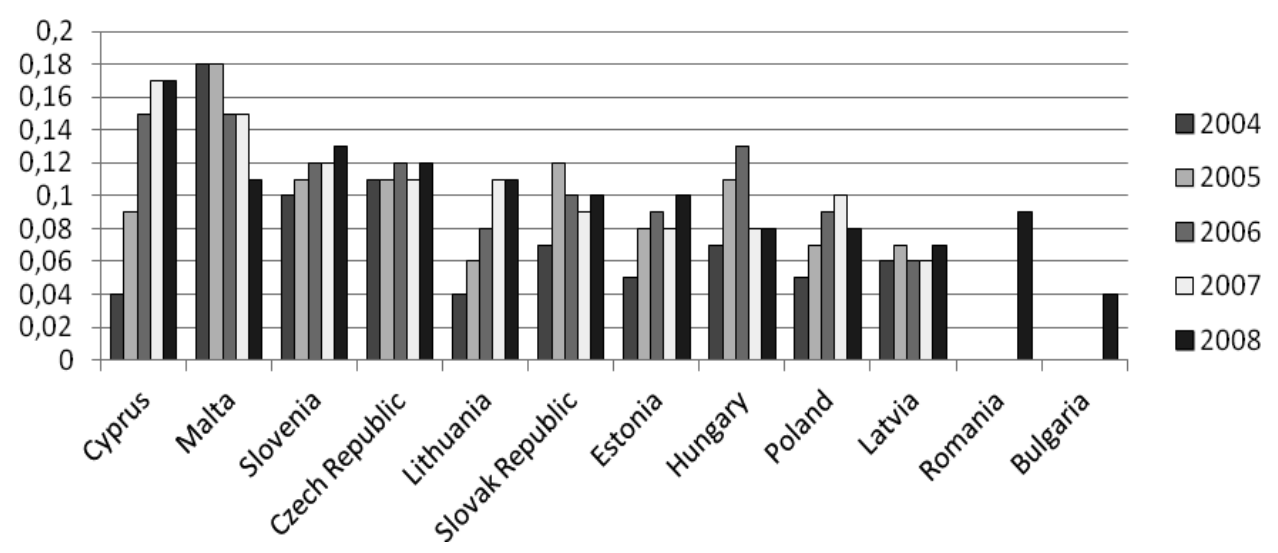

Source: OECD Statistic (2010), own calculation

In comparison with the Member States of the DAC (which seems not comparative because of certain conditions of OECD) the Czech Republic, nor any of the new donor countries, does not reach the minimum share of contributing DAC/EU countries - the smallest donor (Greece) average share of ODA/GNI was $0.18 \%$ in 2004-2008 (see Table 4).

The above comparison, especially connected with efforts of the Czech Republic to be admitted to the DAC, is not overly optimistic. Although the Czech Republic after accession to the EU committed itself to increase its share of ODA to GNI, the goals set for the New Member Countries, $0.17 \%$ ODA/GNI by 2010 and $0.33 \%$ in 2015, it fails to comply. Equally difficult is the fulfilment of the share of bilateral and multilateral aid (70:30, respectively 60:40) - the proportion has the opposite tendency - precisely because of the obligation to contribute to the EU budget. The Czech Republic as one of the four new EU members in 2008 exceeded both the above conditions together with two other traditional multilateral donors Italy and Greece (see Figure 4). 
Table 4

Comparison of EU Member States' ODA as the Average for 2004-2008 (\% of GNI)

\begin{tabular}{|l|l|l|l|l|l|}
\hline Rank & Country & Score & Rank & Country & Score \\
\hline $\mathbf{1 .}$ & Sweden & 0,93 & $\mathbf{1 4 .}$ & Portugal & 0,19 \\
\hline $\mathbf{2 .}$ & Luxembourg & 0,87 & $\mathbf{1 5 .}$ & Greece & 0,18 \\
\hline $\mathbf{3 .}$ & Denmark & 0,82 & $\mathbf{1 6 .}$ & Malta & 0,15 \\
\hline $\mathbf{4 .}$ & Netherlands & 0,79 & $\mathbf{1 7 .}$ & Cyprus & 0,12 \\
\hline $\mathbf{5 .}$ & Ireland & 0,58 & $\mathbf{1 8 .}$ & Slovenia & 0,12 \\
\hline $\mathbf{6 .}$ & Belgium & 0,47 & $\mathbf{1 9 .}$ & Czech Republic & 0,11 \\
\hline $\mathbf{7 .}$ & Austria & 0,43 & $\mathbf{2 0 .}$ & Slovak Republic & 0,10 \\
\hline $\mathbf{8 .}$ & United Kingdom & 0,43 & $\mathbf{2 1 .}$ & Hungary & 0,09 \\
\hline $\mathbf{9 .}$ & France & 0,42 & $\mathbf{2 2 .}$ & Latvia & 0,08 \\
\hline $\mathbf{1 0 .}$ & Finland & 0,41 & $\mathbf{2 3 .}$ & Estonia & 0,08 \\
\hline $\mathbf{1 1 .}$ & Germany & $\mathbf{0 , 3 5}$ & $\mathbf{2 4 .}$ & Poland & 0,08 \\
\hline $\mathbf{1 2 .}$ & Spain & $\mathbf{0 , 3 3}$ & $\mathbf{2 5 .}$ & Lithuania & 0,06 \\
\hline $\mathbf{1 3 .}$ & Italy & 0,21 & $\mathbf{2 6 .}$ & Romania & 0,09 \\
\hline & & & $\mathbf{2 7 .}$ & Bulgaria & 0,04 \\
\hline
\end{tabular}

Source: OECD (2009), OECD Statistic (2010), UN Statistic (2010), own calculation

Note: Data for Romania and Bulgaria are only available for 2008

Figure 4

The Share of Multilateral Aid in the Czech Republic in 2005 and 2008 Compared with Selected EU Member States (in \% of total ODA)

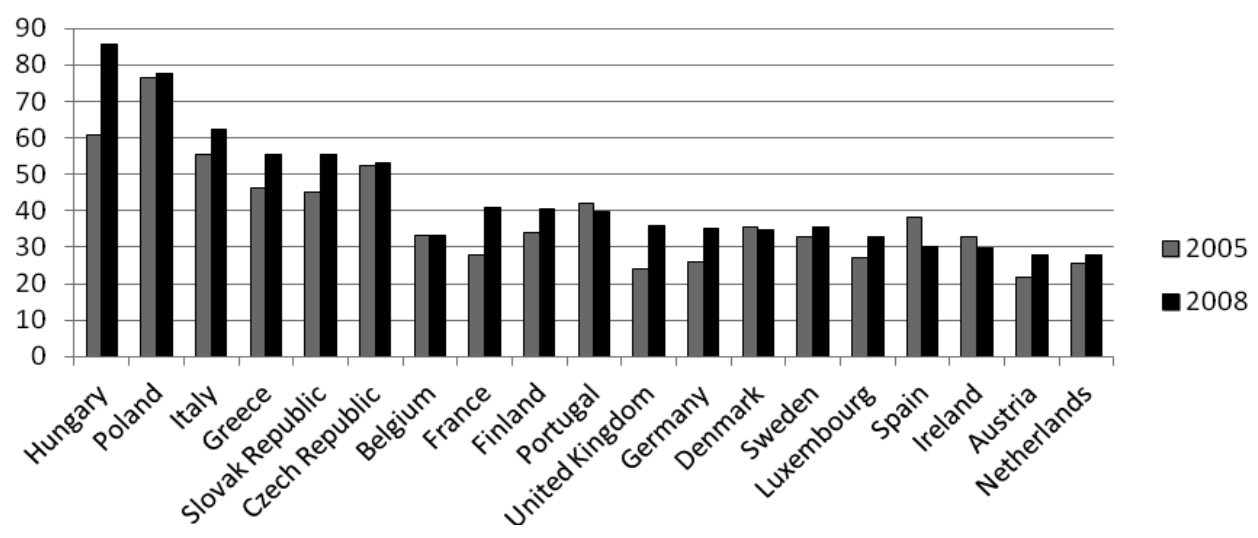

Source: EU (2010) 
All economies have shown an increasing trend, apart from Portugal, Spain and Ireland, which share of ODA is rising slightly. It is closely related to the increasing contributions to the EU budget and the EDF ( $\mathrm{eg}$. in the Czech Republic formed in 2008 contributions to the European Union almost $90 \%$ of total multilateral aid).

In 2009, development assistance grew in absolute terms but nearly half of the Member States of the DAC/EU have reduced the volume of development cooperation citing the impact of financial crisis and also showed similar results with non-DAC states. The decline in absolute amount did not show in the case of the Czech Republic any change in the share of ODA/GNI, Slovakia, however, experienced a drop in both parameters (and thus get to the level of Poland) and Hungary only two indicators increased (and thus received from Slovakia and Poland).

For the years 2010-2012 the Czech Republic is planning to increase its ODA to $0.13 \%$. It is not an substantial increase as compared with Belgium, which plans to increase its spending to $0.7 \%$ ( $+0.15 \%$ change) or Portugal (change of $0.11 \%$ to $0.34 \%$ of the share of ODA/GNI) (OECD, 2008), taking into account the fact that since 2011 the Czech Republic will also contribute to the European Development Fund (EDF) about CZK 3 billion. Other traditional donor countries are planning a gradual increase in assistance, with the exception of the largest donors (Denmark, Luxembourg and Sweden) that can afford this „luxury” given the level of their contributions.

\section{Conclusion}

The current world economy is not homogeneous across countries and regions, there are not only economic differences - while less than $20 \%$ of world population is living in developed economies and this fifth consumes more than $80 \%$ of the world product, twenty percent of the poorest countries consume less than two percent. In one of the means by which developed nations can eliminate such differentiation can be development cooperation (although it is sometimes regarded as a new form of colonialism). Through this assistance, known under the ODA, flows around 60 billion dollars per year - of which EU Member States provide 55\% - for development projects, soft loans, deleveraging, scholarships and food aid and the amount is insignificant in case of unexpected disasters and conflict also humanitarian assistance (the EU itself provides for this type of assistance each year approximately 875 million US \$).

In the Czech Republic (Czechoslovakia, respectively) the foreign development cooperation, as well as in other EU countries, has a tradition since the beginning decolonization processes. During this period, however, it had a strong ideological overtone and helped only those a few developed countries that meet the ideological test. From 1990s of the last century approach to development assistance has changed, which is not related solely to the change of political orientation but in particular the efforts of the involvement of Czech Republic in these economic and political-economic groupings such as the OECD and the EU. 
From 1 July 2010 entered into force on the "Law on International Development and Humanitarian Assistance to Foreign Countries" (Law No. 151/2010 Coll.), which completes the process of transformation and development cooperation: it should be the basis for the Czech Republic's accession to the DAC/OECD. Despite this transition process, which is based on the establishment of the institutional functioning of development cooperation to reduce fragmentation, increase efficiency of cooperation and share of GNI, ODA is subjected to criticism not only from the OECD, but also NGOs in particular because of low efficiency and promotion of national (security, economic and political) interests of the necessity criterion. The total volume of Czech aid is still inadequate because the government does not represent any major budgetary priority (Machálková, 2009).

Donor countries, including the Czech Republic, are of course aware of the need to improve the quality, effectiveness and contribution to development aid recipient economies, especially since in recent years in many economies of donor capacity development cooperation is stagnant or slightly increasing. Big question in this context remains the so-called tied aid, which is linked to non-supply of donor countries and is often criticized because of advancing its own interests economies (on the other hand, why not combine assistance with the growth of the domestic economy operating on the principle of "if I develop myself, I can give you more resources to develop yourself"). Another problem remains a "phantom aid", i.e. assistance not actually available to developing countries to fight poverty (in 2006 was estimated at almost UDS 37 billion) (Shah, 2010). However development assistance, whether many seem it inefficient, plays an important role in the recipient economies and sometimes leading to their passive approach to aid or weakening of competition and destruction of local businesses.

Increasingly the view begins to prevail by donors and international institutions themselves that provide assistance to developing countries should no longer rely on help from others and take responsibility for their own economic development. Instead of providing large funds and donations the developed countries should remove their trade barriers and allow developing countries to participate in international trade. Potential export to developed countries markets would significantly accelerate growth and job creation, thereby promote the development and help reduce poverty in poor countries. 


\section{List of Abbreviations}

$\begin{array}{lll}\text { ACP } & - & \text { Developing countries in Africa, Caribbean and Pacific } \\ \text { DAC } & - & \text { Development Assistance Committee } \\ \text { EBA } & - & \text { Everything But Arms (EU beneficiary trade regime for LDCs) } \\ \text { EC } & - & \text { European Community } \\ \text { ECU } & - & \text { European Currency Unit (1979-1998) } \\ \text { EPA } & - & \text { Economic Partnership Agreement (EU economic cooperation } \\ & & \text { agreement for the reciprocal trade relations with ACP countries) } \\ \text { EU } & - & \text { European Union } \\ \text { GNI } & - & \text { Gross National Income } \\ \text { GSP } & - & \text { Generalised System of Preferences (EU non-reciprocal trade } \\ & & \text { arrangement for ACP countries that guarantees reduced barriers } \\ \text { IDC } & - & \text { International Development Cooperation } \\ \text { LDCs } & - & \text { Least Developed Countries } \\ \text { NGOs } & - & \text { nongovernmental organizations } \\ \text { OA } & - & \text { Official Assistance } \\ \text { OCT } & - & \text { Overseas Countries and Territories } \\ \text { ODA } & - & \text { Official Development Assistance } \\ \text { OECD } & - & \text { Organization for Economic Cooperation and Development } \\ \text { STABEX } & - & \text { Système de Stabilisation des Recettes d'Exportation } \\ & & \text { (EC compensatory finance scheme to stabilise export } \\ \text { SYSMIN } & - & \text { Système de Stabilisation de Recettes d'Exportation } \\ & & \text { de Produits Miniers (EC system of stabilization of export } \\ \text { UNHRC } & - & \text { United Nations High Commissioner for Refugees } \\ \text { UNICEF } & - & \text { United Nations Children's Fund } \\ \text { WFP } & - & \text { World Food Programme }\end{array}$

\section{References}

Adamcová, N. a kol. (2006), Zahraniční rozvojová spolupráce České republiky. Praha: Ústav mezinárodních vztahů.

EU (2007), European Development Fund (EDF). Available at http://europa.eu/legislation_summaries/ development/overseas_countries_territories/r12102_en.htm.

EU (2010a), Aid Channels and Untying Aid. Available at http://fs2-2010.bbj.it/EUDA_03.aspx.

EU (2010b), Aid Resources. Available at http://fs2-2010.bbj.it/EUDA_02.aspx. 
Halaxa, P. (2000), "Zahraniční pomoc ve vztazích vyspělých a rozvojových zemí." In Jehlička, P., Tomeš, J. Daněk, P., eds., Stát, prostor, politika - vybrané kapitoly z politické geografie. Praha: Univerzita Karlova, 2000.

Kaplan, M. (2005), "Rozvojová politika zemí OECD/DAC." Available at http://www.businessinfo.cz/ files/zahranicni-obchod/Rozvojova_politika_zemi_OECD_DAC-090527.pdf.

Kenneth, K. (2002), "Economic Partnership Agreements - Hopes, Fears and Challenges." The Courier ACP-EU. Available at http://ec.europa.eu/development/body/publications/courier/ courier195/en/en_021.pdf.

Kocourek, A. (2006), Podnikatelské aspekty diferenciace rozvojových zemí a rozvojová pomoc České republiky (se zaměřením na země subsaharské Afriky). Liberec: Technická univerzita v Liberci. Available at http://www.alda.name/grafika/DDP.pdf.

Law No. 151/2010, Coll. Zákon o zahraniční rozvojové spolupráci a humanitární pomoci poskytované do zahraniči a o změně souvisejících zákonů (2010). Available at http://www.czda.cz/editor/ filestore/File/Zakon\%20o\%20ZRS\%20151_2010.pdf.

Macrae, J., Harmer, A. (2004), Good Humanitarian Donorship and the European Union: Issues and Options. London: Overseas Development Institute.

Machálková, J. (2009), "Prioritních zemí má být méně." Available at http://www.rozvojovka.cz/ prioritnich-zemi-ma-byt-mene-rozhovor_221_572.htm.

MFČR (2001), Koncepce zahraniční rozvojové pomoci České republiky na období let 2002 až 2007. Praha: Ministerstvo financí České republiky.

MZV ČR (2009), Česká republika pomáhá. Statistická přiloha: Zahraniční rozvojová spolupráce České republiky 2004-2008. Praha: Ministerstvo zahraničních věcí.

MZV ČR (2010), Česká republika pomáhá. Zahraniční rozvojová spolupráce České republiky v roce 2009. Praha: Ministerstvo zahraničních věcí.

Němečková, T., Horký, O., Mazouch, P. (2006), "EU a Afrika jako „noví“ sousedé. Výzvy pro českou zahraniční rozvojovou spolupráci." Výstup z výzkumného projektu v rámci programu GRACES. Praha: VŠE.

OECD (2008), Is it ODA? Available at http://www.oecd.org/dataoecd/21/21/34086975.pdf.

OECD (2009), Development Aid at its highest level ever in 2008. Available at http://www.oecd.org/ document/13/0,3343,en_2649_34487_42458595_1_1_1_1,00.html.

OECD Statistics (2010), ODA by Donor. Available at http://stats.oecd.org/lndex. aspx?DatasetCode=ODA_DONOR.

Preambule Usnesení vlády č. 302 ze dne 31. 3.2004 (2004), Zásady zahraniční rozvojové spolupráce po vstupu České republiky do Evropské unie. Available at http://www.mzv. cz/.../18394_14945_Material_vlada_Institucionalizace.doc.

Shah, A. (2010), "Foreign Aid for Development Assistance." Available at http://www.globalissues.org/ article/35/foreign-aid-development-assistance.

UN Statistics (2010), Net ODA as percentage of EOCD/DAC donors. Available at http://unstats. un.org/unsd/mdg/SeriesDetail.aspx?srid=568.

Vláda ČR (2009), Usnesení vlády České republiky ze dne 15. března 1995 č. 153 k zásadám poskytování rozvojové pomoci. Available at http://racek.vlada.cz/usneseni/usneseni_webtest. nsf/0/7897B04C221A1F30C12571B6006BDB3E.

White, H. (2002), "Long-run Trends and Recent Developments in Official Assistance from Donor Countries." Institute of Development Studies, University of Sussex. Available at http://www.oecd.org/dataoecd/52/16/44376748.xls.

Zahraniční rozvojová spolupráce ČR (2005), Zahraniční rozvojová spolupráce ČR. Available at www.tf.jcu.cz/getfile/5ef56634222c15a2. 